\title{
A new variety of Bacopa monnieri obtained by in vitro polyploidization
}

\author{
Alejandro Salvio Escandón* \\ Instituto de Floricultura INTA-Castelar \\ De los Reseros y Las Cabañas s/n (1712) \\ Buenos Aires, Argentina \\ Tel/Fax: 541144813864 \\ E-mail: aescandon@castelar.inta.gov.ar \\ Juan Carlos Hagiwara \\ Instituto de Floricultura INTA-Castelar \\ De los Reseros y Las Cabañas s/n (1712) \\ Buenos Aires, Argentina \\ Tel/Fax: 541144813864 \\ E-mail: jhagiwara@cnia.inta.gov.ar

\section{Liliana Marisol Alderete} \\ Instituto de Floricultura INTA-Castelar \\ De los Reseros y Las Cabañas s/n (1712) \\ Buenos Aires, Argentina \\ Tel/Fax: 541144813864 \\ E-mail: limarial@hotmail.com.ar
}

Financial support: INTA project number 1837.

Keywords: colchicine, flow cytometry, ornamental plants, Scrophulariaceae, tetraploid.

$\begin{aligned} \text { Abbreviations: } & \text { BAP: 6-benzyl amino purine } \\ & \text { DMSO: dimethylsulfoxide } \\ & \text { MS: Murashige and Skoog (1962) }\end{aligned}$

The commercial value of Bacopa monnieri, a widespread herbaceous plant in Argentina, can be substantially improved increasing its flower size by chromosome doubling with colchicine. MS supplemented with 0.25 $\mathrm{mg} / \mathrm{L}$ of 6-benzylaminopurine proved to be an appropriate medium for the in vitro multiplication of nodal segments of $B$. monnieri. Polyploidization was achieved submerging nodal segments during 24 or 48 hrs in colchicine solution 0.001 and $0.01 \% \mathrm{P} / \mathrm{V}$, in $1 \%$ DMSO. Segments submerged in water and in DMSO $1 \%$ aqueous solution were used as controls. DNA contents from recovered plants was measured and characterized and their phenotype described. Two tetraploid plants originated from independent events were detected. These plants showed significant differences in size and colour both in leaves and flowers compared to untreated controls.

B. monnieri, an herbaceous plant commonly found in temperate regions (Zuloaga and Morrone, 1999), is one of the 12 native species of the genus Bacopa (Scrophulariaceae) present in Argentina. This species has economical relevance as a medicinal plant (Tiwari et al. 2001), a pot plant and as an ornamental in aquatic gardens.
Flower size is one of the traits in $B$. monnieri that needs to be improved to increase the ornamental value of the specie. Polyploidy agents such as colchicines and oryzaline, often used to modify the plant shape and to restorer fertility, are valuable tools to get bigger flowers. These chemicals were successfully applied in the past in many ornamental crops (Horn, 2002) to obtain new genotypes with variants in size and/or colour of flowers and leaves (Notsuka et al. 2000). Chromosome doubling under in vitro conditions is, as well, a very interesting tool for exploration and domestication of wild germplasm to be used as ornamentals (Escandón et al. 2005). Theses improved ornamental products could be either included into a breeding program or transferred to potential users together with the technology developed.

This study presents the tweaking of both the in vitro propagation technique of nodal segments of B. monnieri and the in vitro treatment of this species with colchicine to obtain the new variety Ali INTA-JICA.

\section{MATERIALS AND METHODS}

Tissue culture

*Corresponding author 
Table 1. Nodal segments response of B. monnieri toward different BAP concentrations.

\begin{tabular}{|c|c|c|c|c|c|}
\hline \multirow{2}{*}{ Treatment } & \multicolumn{5}{|c|}{ BAP (mg/L) } \\
\hline & 0.0 & 0.10 & 0.25 & 0.50 & 1.00 \\
\hline Response & (s) $7,25^{\top} \pm 0,39$ & (s) $8,55^{\top} \pm 0,38$ & 3 (s) $18,37^{J} \pm 0,38$ & 3 (c) (s) $17,94^{\mathrm{J}} \pm 0,38$ & (c) (v) \\
\hline
\end{tabular}

Nodal segments of B. monnieri were disinfected in $70 \%$ ethanol for $30 \mathrm{~s}$ and then in a solution containing $25 \%$ sodium hypochlorite: $0.01 \%$ Tween 80 during $25 \mathrm{~min}$. After that, the segments were rinsed three times with distilled and sterile water.

Following disinfection, nodal segments were cultured in a hormone free MS medium (Murashige and Skoog, 1962) to grow the explants needed to study the response of $B$. monnieri to different cytocinine concentrations. The MS medium used for the culture was supplemented with $20 \mathrm{~g} / \mathrm{L}$ sucrose, $7 \mathrm{~g} / \mathrm{L}$ agar, and four growth regulator concentrations: $0.0 ; 0.25 ; 0.5$ and $1.00 \mathrm{mg} / \mathrm{L}$ BAP, $\mathrm{pH}$ was adjusted to 5.7 with $\mathrm{KOH}$. The explants were grown in a 16 hrs light photoperiod under an irradiance of 3,000 lux, and an average temperature of $23^{\circ} \mathrm{C} \pm 2^{\circ} \mathrm{C}$.

After one subculture three or four centimetres long rooted plantlets were transferred to an $8.0 \mathrm{~cm}$ diameter pot containing turf, perlite and vermiculite $3: 1: 1$ (V/V) (Escandón et al. 2003) and kept inside a humidity chamber. The nylon bags used to make the humidity chamber were perforated once per day until no condensation was detected

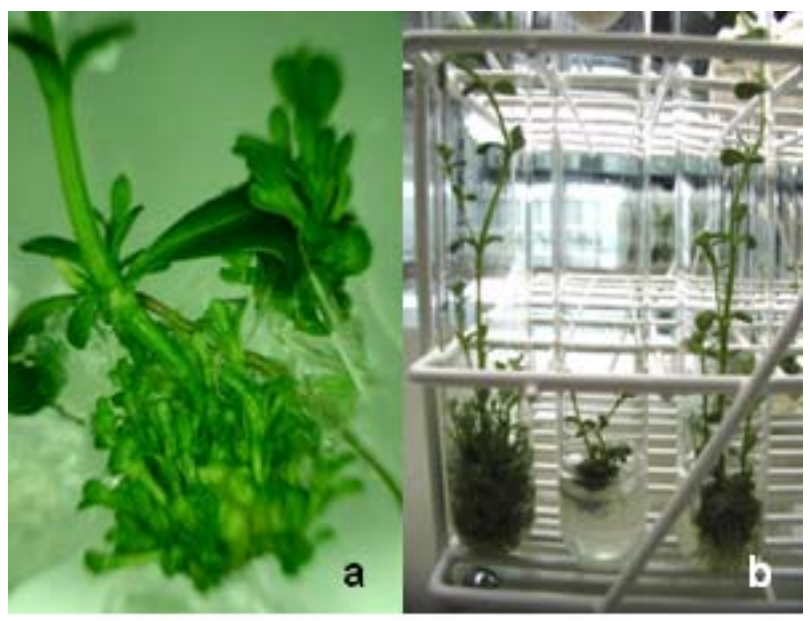

Figure 1. a) Development of lateral buds, de novo morphogenesis from the bottom of the explant and from leaves edge. b) Growth capacity difference between a tetraploid plant (centre) and their control. inside them. Afterwards, the plants were transferred to greenhouse conditions. Twenty explants were used per treatment and the experiment was repeated twice.

\section{In vitro plant polyploidization}

Nodal segments from in vitro plant of $B$. monnieri were submerged in $1 \%$ DMSO solution containing the following doses of colchicine (v/v): $0.0 ; 0.001$ and $0.01 \%$ (24 and 48 hrs). Fifteen untreated nodal segments as well as fifteen segment groups submerged in water or in $1 \%$ DMSO (aqueous solution) were used as controls. The culture medium used for the controls was MS supplemented with $0.25 \mathrm{mg} / \mathrm{L}$ BAP. Culture conditions as well as temperature an photoperiod were the same than in the tissue culture experiments ( $16 \mathrm{hrs}$ light photoperiod under an irradiance of 3,000 lux, and an average temperature of $23^{\circ} \mathrm{C} \pm 2^{\circ} \mathrm{C}$ ).

The ploidy level was determined using the flow cytometer (Partec, CA), following commercial indications: approximately $0.5 \mathrm{~cm}^{2}$ of leaf tissue were chopped with a sharp blade submerged in $0.5 \mathrm{ml}$ nucleus extraction buffer (HR, high resolution, A solution, Partec, CA) and then incubated in the same buffer during $1.5 \mathrm{~min}$. After being filtered, the solution was incubated $1 \mathrm{~min}$ with HR B, Partec, CA. (De Schepper et al. 2001; Sari et al. 1999). The different flow cytometer parameters were adjusted with untreated material to secure well defined and reproducible readings. The nuclear DNA of 150 colchicine treated plants was used in these determinations.

For the phenotype analysis of the recovered treated plants, the diameter of ten flowers and ten stems and the size of the ten leaves were gauged. The stem diameter was measured at the third leaves pair node. Also, the third leaves pair was chosen to measure the ratio length/ wide to establish the size of the leaves. The colour of fifteen leaves and flower was measured by a Minolta CR 321 colorimeter.

Statistical analysis was performed using ANOVA and Tukey test (95\%) supported by the software Statistica 2.0.

\section{RESULTS AND DISCUSSION}

\section{Tissue culture}




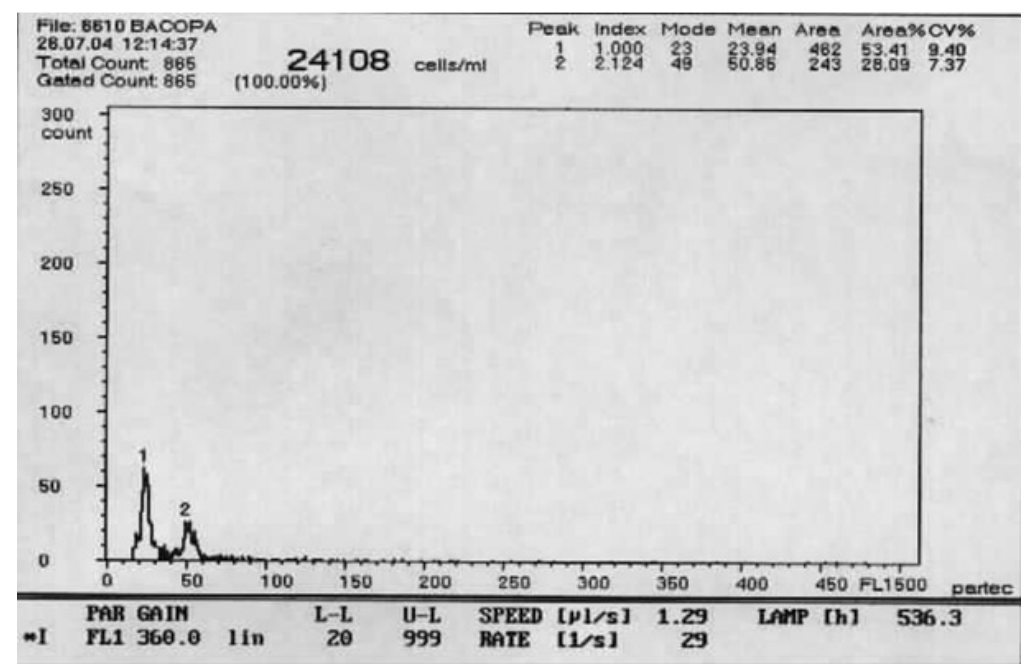

Figure 2. Profiles obtained by flow cytometry of a mixture of a diploid plant and a putative tetraploid one. The peak indicated as " 1 " corresponds to the control without treatment, and the peak indicated as "2" corresponds to a plant treated with a colchicine dose of $0.001 \% 48 \mathrm{hrs}$.

Disinfection experiment showed an efficiency of $80 \%$. B. monnieri did not showed difficulties to grow in vitro conditions. Neither browning nor oxidation processes were detected at the amount of ethanol and sodium hypochlorite used.

Table 1 shows the results obtained with the nodal segments of B. monnieri. Significant differences in the shoots multiplication rate were detected between the treatments containing $0.25 \mathrm{mg} / \mathrm{L}$ and $0.5 \mathrm{mg} / \mathrm{L}$ BAP (18.37 and 17.94 shoots/explant, respectively) and the other treatments. The treatment containing $1.0 \mathrm{mg} / \mathrm{L}$ BAP showed callus production and a very important tissue vitrification. Although callus production was important in the treatment with $0.5 \mathrm{mg} / \mathrm{L}$ BAP, no vitrification was detected in this treatment. Neither callus formation nor vitrification process were found in the $0.25 ; 0.1$ and $0.0 \mathrm{mg} / \mathrm{L} \mathrm{BAP}$ treatments, and except for the $1.0 \mathrm{mg} / \mathrm{L} \mathrm{BAP}$ treatment, in all the others the novo shoots developed from the bottom of the explant

Table 2. Relative sizes and SD between Ali INTA-JICA and their control. The datas are the average of 10 determinations. 1) $\mathrm{mm} 2$; 2) $\mathrm{mm}$; 3) internodal number within 5 $\mathrm{cm}$ of stem measured from the apex.

\begin{tabular}{|c|c|c|}
\hline Organ & Control & Ali INTA-JICA \\
\hline Leaf area $^{1}$ & $30.81 \pm 6.13$ & $79.30 \pm 11.72$ \\
\hline Flower diameter $^{2}$ & $9.4 \pm 1.5$ & $15.1 \pm 1.28$ \\
\hline Stem diameter $^{2}$ & $0.86 \pm 0.09$ & $1.76 \pm 0.24$ \\
\hline Internodal N $^{\circ}$ & $4.0 \pm 0.8$ & $7.6 \pm 0.67$ \\
\hline
\end{tabular}

and at the edge of the leaves (Figure 1a). All recovered shoots rooted spontaneously. No problem was detected for the acclimatization step, all plants transferred to pots were successfully rusticated. These results indicate that for an efficient in vitro micropropagation of $B$. monnieri and in order to avoid undesirable responses, the levels of BAP must be carefully adjusted. In fact, to start with the in vitro polyploidization experiments, the fine-tuning of in vitro micropropagation is required as the first step. The tissue culture experiment in this study showed that $B$. monnier $i$ presented a strict hormonal and nutritional requirement.

Contrasting with the results herein, Tiwari et al. (2001) found, in an experiment in which they compared the effects of different citocinin concentrations, that for $B$. monnieri BAP concentrations higher than $1.0 \mathrm{mg} / \mathrm{L}$ were the adequate for in vitro multiplication of this specie. Not enough data are available to explain adequately the difference between the result presented here and those reported by Tiwari et al. (2001).

\section{In vitro plant polyploidization}

Complete, viable plants of $B$. monnieri were obtained from in vitro growing conditions after the colchicine treatment. Multiplication rate was similar for both, treated and control plants. This result is in agreement with those reported previously by Escandón et al. (2005) with Scoparia montevidiensis, another Schrophulareaceae species working with the same colchicine doses $(0.001$ and $0.01 \%$, 24 and $48 \mathrm{hrs}$ ). The only difference observed under in vitro conditions between the control and the colchicine treated plants was growing capacity: treated plants grew less compared to the controls (Figure 1b). 


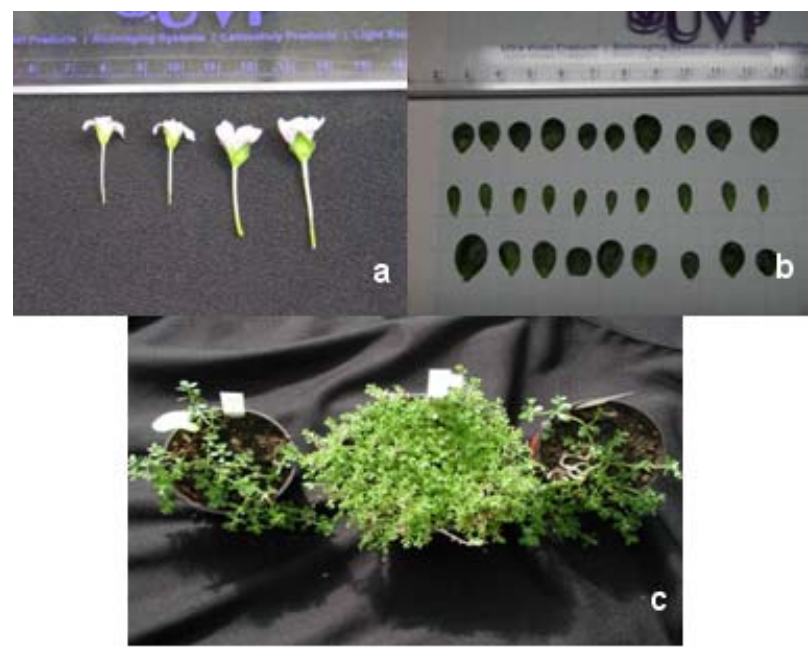

Figure 3. Relatives sizes of:

a) Flowers.

b) Leaves.

c) Entire plants (diploids arrowed).

Two tetraploid individuals out of 150 colchicine treated plants were recovered. Figure 2 shows the peak readings obtained by flow citometry analysis of a mixture of diploid and tetraploid tissues. Peak "1", with a mean relative DNA content of 23.94, corresponds to the control cells, whereas peak "2", with mean relative DNA content of 50.85 corresponds to the tetraploid cells. The cell concentration of the mixture was 24,108 cells $/ \mathrm{mL}$ and the total populations cells counted was 865 .

Leaf area, flower diameter, stem diameter and number of internodes were significantly different in the recovered tetraploid plants compared to the control (Table 2). Figure 3 shows the differences in size, aspect and shape between flowers (panel "a") and leaves (panel "b") referred to in the
Table 2. In panel "c" it can be seen that the different growth capacity observed in vitro (Figure 1b), is maintained in vivo.

Colour analysis made both in treated and control plants is summarized in Figure 4. Panel "a" shows the different distributions of colour intensity of the tetraploid plant flowers compared to the controls. Differences in colour, size and firmness are apparent in panel "b" in which tetraploid (arrowed) and diploid flowers are shown in detail. Enlargement of organs (flowers and leaves), intensification of colours, hardier and more robust plants, thicker and more rigid foliage, an discernible increase in the tolerance to different stresses, and the resistance to diseases and pests (Petit and Callaway, 2000) are associated with chromosome doubling, a frequent natural event in ornamental species (Horn, 2002). Thus, chromosome doubling is accepted as a source of evolution of flowering plants, and breeders benefit from it for the domestication of certain genotypes (Van Tuyl and Lim, 2003). Actually, this strategy was extensively used during the last 30 years in many species such as banana (Baziran and Ariffin, 2002), grapes (Notsuka et al. 2000), blueberry (Lyrene and Perry, 1982), potato (Hermsen et al. 1981), and sugarcane (Heinz and Mee, 1970). Under in vitro controlled conditions polyploidization was employed in several ornamental crops, such as Alocasia (Thao et al. 2003), Rhododendron (Eeckaut et al. 2002; Väinölä, 2000), Cyclamen (Takamura and Miyajima, 1996; Ishizaka and Uematsu, 1994).

It was widely demonstrated that the in vitro colchicine treatment is a powerful tool for breeding ornamental germplasm (Horn, 2002). In our laboratory interesting results were obtained with different genera. The results herein add to previous studies in the genera Scoparia (Escandón et al. 2005) and Calibrachoa (Hagiwara et al. 2002).

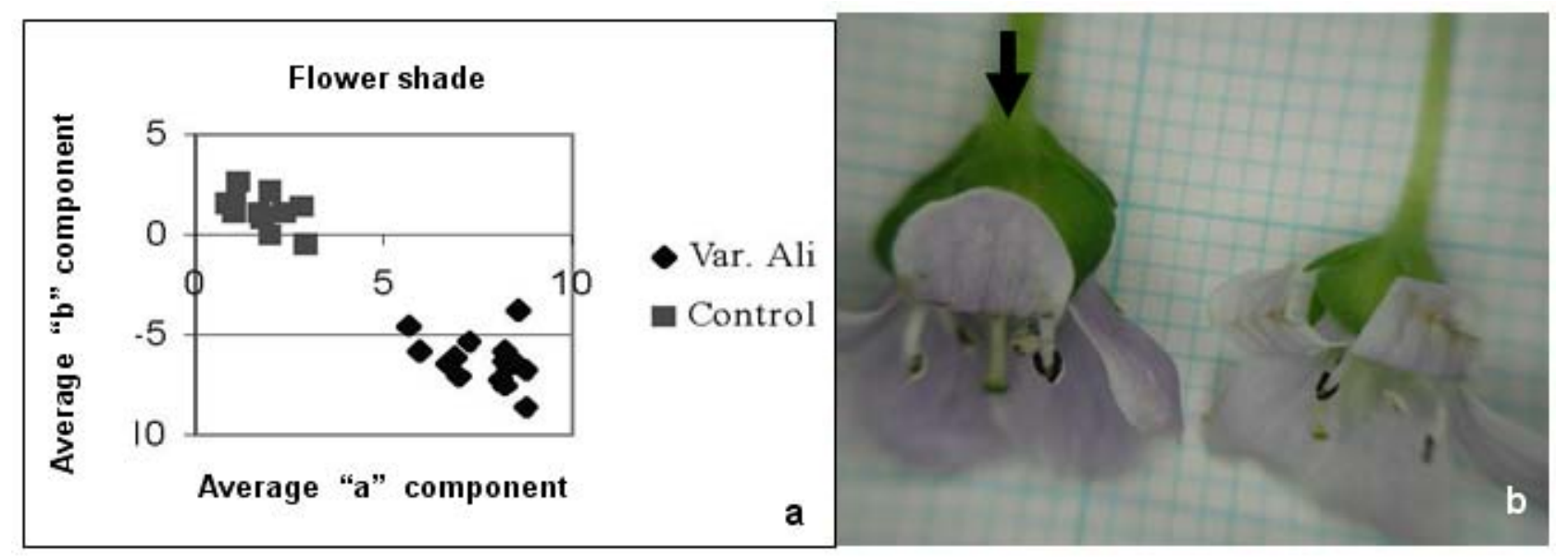

Figure 4. a) Distribution of the colour shade of: the tetraploid and the diploids flowers, where "a" and "b" are parameters measured by the Minolta CR 321 colorimeter. b) The row indicates the tetraploid flower; the differences in colour, size and firmness between them are evident. 


\section{REFERENCES}

BAZIRAN, N. and ARIFFIN, S. The progress and potentials of mutation induction in vegetatively propagated plants in Malaysia. Malaysian Institute for Nuclear Technology Research (MINT) [cited 26 September 2003] Portable Document Format. Available from Internet: http://www.fnca.jp/english/fnca/2_totuzenheni/3/2002ws/0 4/04malasya/main.html.

DE SCHEPPER, S.; LEUS, L.; MERTENS, M.; VAN BOCKSTAELE, E. and DE LOOSE, M. Flow cytometric analysis of ploidy in Rhododendron (subgenus Tsutsusi). HortScience, 2001, vol. 36, no. 1, p. 125-127.

EECKAUT, T.; SAMSYN, G. and VAN BOCKSTAELE, E. In vitro polyploidy induction in Rhododendron simsii hybrids. In: VAN HUYLENBROECK, J.; VAN BOCKSTAELE, E. and DEBERGH, P. eds. Proceedings of $X X$ EUCARPIA Symposium on New Ornamentals II. $\left(3^{\text {rd }}-\right.$ $6^{\text {th }}$ July 2001) Acta Horticulturae, 2002, vol. 572, p. 43-49.

ESCANDÓN, A.S.; FERRARI, P.; FACCIUTO, G.; SOTO, S.; HAGIWARA, J.C. and ACEVEDO, A. Combinación de técnicas in vitro y ex vitro para la micropropagación de Santa Rita (Hibr.). Una arbustiva de relevancia ornamental. Revista de Investigaciones Agropecuaria, April 2003, vol. 32, no. 1, p. 111-122.

ESCANDÓN, A.S.; MIYAJIMA, I.; ALDERETE, M.; HAGIWARA, J.C.; FACCIUTO, G.; MATA, D. and SOTO, S. Wild ornamental germplasm exploration and domestication based on biotechnological approaches. In vitro colchicine treatment to obtain a new cultivar of Scoparia montevidiensis. Electronic Journal of Biotechnology [online]. 15 August 2005, vol. 8, no. 2 [cited 30 August 2005]. Available from Internet: http://www.ejbiotechnology.info/content/vol8/issue2/full/2/ index.html. ISSN 07173458.

HAGIWARA, J.C.; KATO, A.; MORI, M. and MIYAJIMA, I. Obtención de poliploides en Calibrachoapygmaea mediante el uso de colchicina in vitro. In: 1er. Congreso Argentino de Floricultura y Plantas Ornamentales. 4tas. JornadasNacionales de Floricultura $\left(13^{\text {th }}-16^{\text {th }}\right.$ November, 2002), Buenos Aires, Argentina. Summary Book, Faculty of Agronomy, UBA, 2002, p. 90.

HEINZ, D.J. and MEE, G.W.P. Colchicine-induced polyploids from cell suspension cultures of sugarcane. Crop Science, 1970, vol. 10, no. 6, p. 696-699.

HERMSEN, J.G.; RAMANNA, M.S.; ROEST, S. and BOCKELMANN, G.S. Chromosome doubling through adventitious shoot formation on in vitro cultivated leaf explant from diploid interespecific potato hybrids. Euphytica, 1981, vol. 30, no. 2, p. 239-246.
HORN, W. Breeding for Ornamentals. In: VAINSTEIN, A. ed. Classical and Molecular Approaches. Kluwer Academic Publisher, Netherlands, 2002, p. 47-83.

ISHIZAKA, H. and UEMATSU, J. Amphidiploids between Cyclamen persicum Mill. and C. hederifolium Aiton induced through colchicine treatment of ovules in vitro. Breeding Science, 1994, vol. 44, no. 2, p. 161-166.

LYRENE, P. and PERRY, J.L. Production and selection of blueberry polyploid in vitro. Journal of Heredity, 1982, vol. 73 , no. 5 , p. 377-378.

MURASHIGE, T. and SKOOG, F. A revised medium for rapid growth and bioassays with tobacco tissue cultures. Physiologia Plantarum, 1962, vol. 15, p. 437-497.

NOTSUKA, K.; TSURU, T. and SHIRAISHI, M. Induced polyploidy in grapes via in vitro chromosome doubling. Journal of Japan Society of Horticulture Science, 2000, vol. 69 , no. 5, p. 543-551.

PETIT, T.L. and CALLAWAY, D.J. Breeding daylilies (Hemerocallis). In: CALLAWAY, D. and CALLAWAY, M.B. eds. Breeding Ornamental Plants. Timber Press, Portland, Oregon USA, 2000, p. 49-73.

SARI, N.; ABAK, K. and PITRAT, M. Comparison of ploidy level screening method in watermelon: Citrulluslanatus (Thunb.) Matsum. and Nakai. Scientia Horticulturae, 1999, vol. 82, no. 3-4, p. 265-277.

TAKAMURA, T. and MIYAJIMA, I. Colchicine induced tetraploids in yellow-flowered cyclamens and their characteristics. Scientia Horticulturae, 1996, vol. 65, no. 4, p. 305-312.

THAO, N.T.P.; URESHINO, K.; MIYAJIMA, I.; OZAKI, $\mathrm{Y}$. and OKUBO, H. Induction of tetraploids in ornamental Alocasia through colchicine and oryzalin treatments. Plant Cell Tissue and Organ Culture, 2003, vol. 72, no.1, p. 1925.

TIWARI, V.; TIWARI, K.N. and SINGH, B.D. Comparative studies of cytokinins on in vitro propagation of Bacopa monnieri. Plant Cell; Tissue and Organ Culture, 2001, vol. 66, no. 1, p. 9-16.

VÄINÖLÄ, A. Polyploidization and early screening of Rhododendron hybrids. Euphytica, 2000, vol. 112, no. 3, p. 239-244.

VAN TUYL, J.M. and LIM, K.B. Interspecific hybridization and polyploidization as tools in ornamental plant breeding. In: FORKMAN, G.; HAUSER, B. and Michaelis, S. eds. Proceedings of the $21^{\text {st }}$ International Symposium on Classical versus Molecular Breeding of Ornamental ( $25^{\text {th }}-29^{\text {th }}$ August, 2003, München, Germany) Acta Horticulturae, 2003, vol. 612, p. 13-22. 
Escandón, A. S. et al.

ZULOAGA, F.O. and MORRONE, O. Catálogo de Plantas Vasculares de la República Argentina. In: Monographs in Systematic Botany from the Missouri Botanical Garden. Missouri Botanical Garden Press, 1999, vol. 74, p. 10371038. ISBN 0-915279-65-7. 